\title{
Pensions: The new world of divorce
}

Received: 16th November, 2001

\section{Bernard Brindley}

is a Principal of Hazell Carr Collins, Consulting Actuaries. He has been an active member of the actuarial profession; he has been Treasurer, a member of the Council, the Pensions Board and the Life Board. Bernard was involved in the recent Equitable Life case as an expert witness called on behalf of the policyholder who was joined in a representative capacity as Claimant. He has been instructed as a forensic expert on many occasions, particularly in pensions matters in divorce cases.

\begin{abstract}
This paper sets out the new situation regarding pensions on divorce following pension sharing as established by the Welfare Reform and Pensions Act 1999 (WRPA). It deals with pensions as deferred pay and the capital nature of pensions; it then illustrates the illogicality of treating assets inside and outside a pension scheme differently. It deals with the way in which pension rights can be offset against other assets in a fair way by treating tax consistently. The paper explains the dangers of using some Cash Equivalent Transfer Values without expert advice, for example for the uniformed services; and how pension sharing can be made to be fair in these circumstances. An example is given about the effect of ill-health. An example of part-offsetting and part-sharing is given, and attention is drawn to the investment aspects of pension sharing.

The paper concludes by pointing out that pension rights in the UK are enormously valuable and therefore important in divorce. At the same time they are complicated and there are plenty of traps for the unwary.
\end{abstract}

Keywords: pensions; divorce; (pension) sharing; Welfare Reform and Pensions Act 1999; actuarial advice; Cash Equivalent Transfer Values (CETV)

Bernard Brindley Hazell Carr Collins, Consulting Actuaries, 8 Sydenham Avenue, London SE26 6UH, UK.

Tel: $+44(0) 208776$ 6374; Fax: +44 (0)20 8766 9445; E-mail: bernard.brindley@ cpssl.com

\section{Introduction}

Pension rights are now a major asset in many families. For some they are the largest item amounting to more than the equity in the family home. Thus it is incumbent on those advising on divorce to recognise the real nature and value of pension rights, and ensure that they are treated correctly.

The readership of this journal is largely those for whom pensions are a familiar topic. In this paper the author hopes to give some insight into the issues that concern those people with pensions rights who are divorcing and the lawyers who are advising them.

In the rest of this paper it is assumed that it is the husband who is the pension scheme member.

\section{Pension rights are deferred pay}

There has been much confusion over the nature of pension rights and how they should be handled at divorce. Frequently the pension has been mistakenly regarded as future income, with reliance placed on arbitrary projections of possible benefits. 
The recent White and Cowan judgments and the introduction of Pension Sharing have in their different ways highlighted the error of treating pensions as 'income'.

The European Court of Justice Barber $v$ GRE case in 1990 on sex discrimination established clearly the concept of pension rights as deferred pay. It ruled that pensions paid under Occupational Pension Schemes fall under the scope of the Treaty of Rome within its principle of 'equal pay for equal work'. This applies whether the pay is direct or indirect, immediate or deferred.

Therefore, the individual's pension rights are a capital asset earned during the marriage. They should be treated as such along with the other capital assets of the couple. The only difference is that the value to be attributed needs some consideration.

\section{Capital value of the pension}

Like all assets, pension rights can be assigned a capital value. This is not a market value. Unlike houses, cars, shares, and so on, pension rights cannot be bought and sold. They cannot be assigned for value. They cannot be encashed.

Nevertheless, the couple who are divorcing need to have a basis on which to divide up the assets they have accumulated during their marriage (and, in England and Wales although not in Scotland, perhaps also assets acquired before or after the marriage). It is relatively easy when it is 'you can have the Porsche if I can keep the silver'. But it is not quite so obvious if it is a house and pension rights. For this purpose pension rights are best valued in terms of their replacement value.

The concept of the capital value of pensions is recognised inter alia by the Welfare Reform and Pensions Act 1999 in respect of pension sharing. It is the Cash Equivalent Transfer Value (CETV) that is used as the basis for the spouse's share, ie, a capital amount. The choice of the CETV was purely pragmatic, and the whole pensions industry has the machinery to calculate them.

However, the concept of the CETV was not invented for the purpose of offsetting the value of pension rights against the value of houses, cars, and so on. It was developed to enable occupational pension schemes to pass on the liability for the pension rights of an employee who is changing his job from the previous employer's pension scheme to the new employer's pension scheme. Incidentally, that is another example of treating pension rights as a capital sum.

At divorce the spouse can be awarded a sum of money in lieu of the pension rights. This would be calculated as the amount that would allow her to replace what she has lost. Of course this sum would be invested outside a pension scheme, but she could, if she wished, buy a pension with it. If she did not have the opportunity to buy an approved pension with the corresponding tax treatment, she could simply invest the money normally until retirement and then at retirement she could buy a Purchased Life Annuity (PLA). From a tax point of view, that would mean she was taxable until retirement but then she would have the advantage of the more favourable tax treatment of the PLA.

\section{A fair division of capital assets}

The Pensions Act 1995 and the White and Cowan cases have made it clear that the value of the assets owned by the couple should be fairly divided. Assets include the value of pension rights.

The obligation for fair division of capital assets is argued by the Honourable Mr Justice Singer in 'Sexual 
Discrimination in Ancillary Relief in the February 2001 edition of Family Law.

To illustrate the argument, Mr Justice Singer sets out the hypothesis of a couple, $\mathrm{Mr}$ and Mrs Litmus:

'He was 19 and she was 24 when they married, 35 years ago. They had no capital to start with. She worked until the birth of the first of their three children, each of whom has now left home, married and become financially independent. Since she stopped work the wife has looked after the household and the family, and done everything that the husband and indeed the world would have expected from a woman in her social situation. Thus there was no expectation that she would resume employment as the children grew up.

The family meanwhile prospered. The husband's company, in the success of which the wife played no direct part and in which she never held either shares, office, or even "employment", has been sold for a handsome sum and he has effectively retired from business life. Since their recent separation each has acquired their own home with which they are respectively content, so their housing needs are satisfied. All the rest of the family's wealth is liquid and in his name, for he always regarded the company as his pension fund, to be disposed of when the price was right, and so made no separate provision.

He is now 54 and she is 59 , so that you can tell from the life tables in At A Glance that they share the same life expectancy. Their needs, therefore, are precisely similar in terms of what they each require to maintain a standard of living commensurate with that style they enjoyed during cohabitation. Those needs can easily be met from available resources, with lots left over besides. Conduct is of no importance; both are in good health; each seeks a clean break, and there is obviously no practical difficulty in effecting one.'

He goes on to argue the case for fair division, 'fair' being 50/50, in these highly convenient circumstances. In more complicated situations the starting point is still 50/50 although the usual issues of children, housing, and so on will all have their effects.

\section{Effecting a fair division of pension rights}

Now that it is possible to share (or split as it used to be known), there are three options open to a divorcing couple in order to give effect to a fair division of pension rights:

- sharing

— offsetting

- earmarking.

Earmarking is unsatisfactory from quite a number of points of view. Consequently, it has been little used since it was introduced by the Pensions Act 1995. In the future it is likely to be even less used now pension sharing is available. This paper will therefore concentrate on sharing and offsetting.

\section{A pension share}

If there were pension rights in the circumstances of $\mathrm{Mr}$ and Mrs Litmus, a pension share would be straightforward. For example, if the CETV were $f 1 \mathrm{~m}$, each would get $f^{0.5 m}$ (less a bit for expenses) and, because of their similar life expectations, they would receive approximately the same gross pension. There are no tax complications.

It will be interesting to see, as pension sharing becomes more used, what will happen in the absence of the simplifying assumption of similar life expectations. The pension sharing regulations are clear. If the pension sharing Order asks for a 50 per cent share, that is applied to the CETV. Thus were Mrs Litmus equal in age to her husband, or younger, she would get a smaller annual pension due 
to her longer life expectation, albeit a pension that would be likely to be paid for longer.

So the argument will often be: husband - 'fairness means equal capital values'; wife - 'fairness means equal incomes'. The unambiguous position in the WRPA is that the value of pension rights is the CETV and that a 50 per cent share is defined by reference to that sum, even if it produces a smaller pension for the wife (usually). If a couple were to agree that they wanted an equal income it would need an actuarial calculation to establish what the share should be, say 55 per cent to 45 per cent in her favour.

\section{Offsetting}

Suppose that Mr Litmus wanted to keep his pension rights with their CETV of f.1m. He might prefer to pay Mrs Litmus with other assets and settle it in that way. That is, he would settle on a replacement value basis. In these circumstances, as mentioned above, tax issues would arise:

- The pension from an approved pension scheme is fully taxable. If Mrs Litmus chooses to buy a PLA pension from this replacement value, the taxation treatment will be considerably more favourable.

- If she chooses to keep the cash invested for a while before buying a pension, the investment income, and possibly the capital gains will be taxable, which would not be the case in the pension scheme.

The net effect of these two factors is that since the couple are close to retirement, she will need less than $f^{0.5 m}$ for fair treatment. Had she been much younger the second tax effect would carry more weight, and the reverse might be true.
There is another matter that will be for negotiation rather than calculation. She does not have to buy a pension since her cash is outside an approved pension scheme. He will have no choice but to buy a pension. This allows the argument to be introduced that unencumbered investments are more valuable than investments that are 'tied up' in a pension scheme. Mr Litmus will presumably use this argument to try to reduce a 50/50 share to, say, 55/45 in his favour.

\section{The White and Cowan cases}

These two judgments lead to the following treatment of capital, putting in typical figures for a reasonably well-to-do family in their early 50s:

$\begin{array}{lr}\text { Value of the equity } & \\ \text { in the house } & \\ \text { Stocks, shares, bank } & \\ \text { accounts, etc } & \\ \text { Cars and other assets } & \\ \text { His pension } & \\ \text { Her pension } & \\ \text { Total } & \\ \text { Each share } & \end{array}$

In this example pensions account for almost three-quarters of the total assets. These typical values emphasise just how important it is to include the pensions in the consideration of capital on divorce.

\section{The importance of realism}

The issue, however, is more complex. For a variety of technical reasons, in a minority of cases CETVs are not always realistic. As has been mentioned, CETVs were devised to enable one pension scheme to transfer its liability for a transferring employee's pension rights to another pension scheme. Therefore the CETV is calculated on the basis of: 
- no tax

- normal good health

- leaving service benefits

- pension scheme investment criteria.

There are situations where one or more of these does not apply and this can lead to some big discrepancies. Some examples are as follows:
For a pension scheme member who is:

a police sergeant with 25 years' service

an army sergeant with 17 years' service

a well-to-do man near retirement at 60 with a CETV of $f, 1 \mathrm{~m}$

a man, aged 60, about to retire on a pension of f,10,000 per annum and with a heart condition the result of using the CETV is: the pension is under-valued by about $, 120,000$ the pension is under-valued by about 880,000 the pension is over-valued by about $\mathcal{1} 160,000$

the pension is over-valued by about 670,000
So these cases, where the CETV is not a good guide to the replacement value of the pension rights, invite the question as to how a pension share should be arranged if a fair result is to be achieved?

A particular situation arises in the following pension schemes. Where the husband is a member of the:
Police Force

Fire Brigade

Armed Forces he can retire from 50 depending on service he can retire from 50 depending on service he can retire from 40 depending on rank
Prison Service

(where service

started before

November 1987)

NHS scheme

(certain members

only, as mental

health officers and midwives) he can retire from 55 depending on service

he can retire at 55
There are two complications which stem from the different ages at which the pensions can start. These ages are:

- If the husband remains in service until retirement, the pensions start at the ages shown above

- If the husband leaves service before retirement, his pension starts at age 60 .

After a pension share the wife's pension must start at age 60. The Government Actuary's Department has indicated that there will be no flexibility in this. There will not be the option to take an actuarially reduced pension from an earlier age as there is in many private sector schemes.

Dealing first with the husband's situation, evidently a pension payable from age 60 is worth substantially less than a pension from, say, age 50 . The CETV is always calculated on the assumption that the member has already left service, ie, that the pension starts at age 60 . The result of this is that the CETV is always a significant understatement of the true value of the pension rights.

Turning to the wife, the regulations are absolutely clear that a pension share must be based on a percentage of the CETV. Therefore if the CETV is an under-valuation of the pension rights, an adjustment must be made if she is to receive fair treatment.

The first complication is that in cases where the CETV is not a realistic value of 
the pension rights, the pension share must be based on an independent value of the pension rights and then re-expressed in terms of the CETV. An example will help clarify how this is done.

A policeman is almost 50 , by which time he will have served for 30 years, having started at age 20 . His salary is $£ 30,000$, which means he can retire with a pension of $£ 20,000$ per annum and on his death his widow will receive a pension of $\mathcal{E} 10,000$ per annum. (He has the option to cash a quarter of his own pension for a tax-free lump sum of £ 75,000 .)

- The CETV is $£ 250,000$. This value is based on his starting his pension at age 60 , ie, assuming he leaves the police force. This is clearly an entirely unreasonable assumption.

- A realistic value of his pension rights is based on his pension starting at age 50 and is 6400,000 .

If the couple agrees that the pension is to be shared 50/50 the adjustment process is:

Realistic value of the $\quad \mathcal{E} 400,000$ pension rights

Each party's share $£ 200,000$

The wife's share will $£ 200,000$ need to be expressed as a percentage of the CETV which is $£ 250,000$

The police scheme will then use 80 per cent of the CETV (ie, 80 per cent of $\mathcal{E}^{250,000}=\mathcal{E}^{200,000)}$ to provide a pension for his wife. So that leads to a pension for her starting at age 60 of perhaps $\mathcal{f} 15,000$ and on her death her widower (if any) will receive a pension of $\mathcal{E} 7,500$ per annum. (She also has the option to cash a quarter of her pension for a tax-free lump sum of $£ 54,000$.)
So this leads to the second complication. At the moment the situation is:

- He has a pension debit of 80 per cent of his pension, which is $£ 16,000$ $(=80$ per cent of $£ 20,000)$ apparently leaving him with only $£ 4,000$.

- She has a pension credit of $£ 15,000$, which is less than his debit because as a woman her life expectation is greater than his.

This conundrum is resolved by, in the phrase used in the explanation given to the husband by the scheme, if he retires before age 60 [which we know he will in this example] his pension debit will be actuarially adjusted to compensate for beginning to deduct the pension debit from an earlier age'. So his pension debit will not be $\mathcal{E} 16,000$ but a reduced amount, about $£ 10,000$.

So the final position will be, when he retires at 50 :

- He has a pension debit of about $\mathcal{L}_{10,000,}$ which starts at age 50 .

- She has a pension credit of $£ 15,000$, which starts at age 60 .

So a pension of $£ 20,000$ has been split into two pensions totalling $\mathcal{E}^{25,000 !}$ However, if the Pension Sharing Order been done on a naïve, albeit understandable, basis of 50 per cent the result would become:

- He has a pension debit of 50 per cent of his pension, which, after the 'actuarial adjustment', becomes is $£ 6,250$ leaving him with $£ 13,750$, which starts at age 50 .

- She has a pension credit of $£ 9,375$, which starts at age 60 .

Clearly this is a gross miscarriage of the couple's intention to share the pension 
equally. Sad to say, there are still some unresolved difficulties:

- The basis of the actuarial adjustment is not yet known. It is assumed it will be consistent with the CETV basis, although there has not been written confirmation of this.

- In the example the situation has been simplified by assuming the policeman was close to 50 and would be virtually certain not to leave. Had the situation been less extreme, say if he were 40 , it would not be certain that he would remain in service to retirement. If he was certain that he was going to leave, a 50 per cent share in the Order would be fair. The practical answer is for a compromise to be arrived at between the alternatives. The closer the husband is to retirement, the closer the value should be to the 'not leaving' result.

A similar approach can be used for other circumstances. In the ill-health example above, the logic would be:

- The CETV is $£ 350,000$. The value is based on the assumption that he is in normal good health. This is clearly an unreasonable assumption in the light of his heart condition.

- A realistic value of his pension rights is based on his pension starting at age 50 and is $\mathcal{E}^{2} 280,000$.

If the couple agrees that the pension is to be shared 50/50 the adjustment process is:

Realistic value of the pension rights

Each party's share

$£ 280,000$

The wife's share will

$£ 140,000$ need to be expressed as a percentage of the CETV which is £350,000
The pension sharing Order should then specify 40 per cent.

Another issue that arises is how does a pension share work in combination with offsetting? In this case, the offsetting calculation must take tax into account and be on prudent investor assumptions while the sharing calculations do not need to.

This means that, even if the wife has the house and all the other assets, the only satisfactory way to arrive at a fair division is to partly share the pension. This leads to the following situation.

First the total assets in the marriage must be divided. As has been explained, pension rights do not have a market value like houses, cars and shares, but they certainly have a replacement value. That is, if the couple were to remain married the wife would enjoy support from her husband's pension, net, of course, of his tax. If they divorce she can be given such a sum of money that replaces her share of this benefit. Of course this sum would be outside a pension scheme, but she can if she wishes buy a pension with it.

The correct tax treatment in valuing his pension rights is to allow for three tax effects:

- His pension will be fully taxable

- If she chooses to buy a pension she will be only partly taxable on it

- During the period between divorce and her retirement, she must save the sum she has been given and the investment return on this sum will be taxable.

There is also an important investment point. She will be in the position of a 'prudent investor'. She will not wish to risk her sum — which should provide her pension - by investing in equities. A more reasonable attitude for her to take is to invest in index-linked gilts; she 
then is protected against inflation and has a guaranteed return. (This is the underlying rationale in the Wells case; although that case was concerned with damages, the point is virtually identical.)

These factors make the CETV unsuitable. This is because the CETV is calculated by the pension scheme actuary who assumes:

- no tax - since pension schemes are virtually tax-free

— high investment returns — since pension schemes invest substantially in equities in the hope of achieving better long-term results.

These differences become most important in the larger cases. Consider the following example. A company executive earns $\mathcal{E} 100,000$ and is about to retire at age 60 from his firm's private pension scheme. He has worked for the firm throughout his career and will retire with a pension of $£ 50,000$, a widow's pension of $\mathcal{L}^{44,444}$ and a tax-free lump sum of $£ 150,000$. His wife is three years younger than he is.

- The CETV is about $\mathcal{E} 1,240,000$.

- Assuming that he is in normal good health for his age, an actuarial valuation of the pension rights, allowing for tax at 40 per cent and investment criteria for a prudent investor, is about $£ 870,000$.

Suppose the equity in the house and all the other assets in the marriage amount

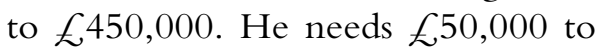
provide a car and a deposit on a house. He is keen to keep as much of his pension as possible, so the couple agree - in the light of White and Cowan - as shown in Table 1.

The Regulations deriving from the Welfare Reform and Pensions Act 1999 say that the pension share must be based on the CETV. Hence the pension sharing Order should be based on the CETV and on husband 70 per cent, wife 30 per cent.

The replacement value approach is not now relevant because the value of the pension rights is not being compared with non-pension assets. Now both husband and wife:

- are in a tax-privileged pension scheme - so an allowance for tax is unnecessary

- will be taxable on the full amount of their pensions (his tax rate may be higher than hers, but in this context that is normal, unless there was an agreement to equalise their net incomes)

- are in an equity-investment orientated pension scheme - so prudent investor criteria do not apply.

The vital importance of this can be demonstrated by following through what the result would have been if an independent value not been sought and the CETV used. Table 1 would change to that shown in Table 2.

Consequently the Order would be based on husband 64 per cent, wife 36 per cent.

\section{A pension share can be an investment decision}

There is another tricky and important aspect. Suppose a pension Scheme member also has a frozen pension from a previous employment. Which pension should he share? Scheme actuaries have some discretion in the basis they choose, reflecting for example the investment policy of the pension scheme trustees. Suppose that one CETV is generous and the other is 'stingy'. The husband would be well advised to share the generous one. Of course, it is vice versa for the wife. 
Table 1

\begin{tabular}{|c|c|c|c|}
\hline & $\begin{array}{l}\text { Husband } \\
£\end{array}$ & $\begin{array}{l}\text { Wife } \\
£\end{array}$ & $\begin{array}{l}\text { Total } \\
£\end{array}$ \\
\hline Division of non-pension assets & 50,000 & 400,000 & 450,000 \\
\hline Division of pension rights & 610,000 & 260,000 & 870,000 \\
\hline Total & 660,000 & 660,000 & $1,320,000$ \\
\hline \multirow[t]{3}{*}{ Pension share expressed as a percentage } & $\underline{610,000}$ & 260,000 & \\
\hline & $\overline{870,000}$ & $\overline{870,000}$ & \\
\hline & $=70 \%$ & $=30 \%$ & $100 \%$ \\
\hline
\end{tabular}

Table 2

\begin{tabular}{|c|c|c|c|}
\hline & $\begin{array}{l}\text { Husband } \\
£\end{array}$ & $\begin{array}{l}\text { Wife } \\
£\end{array}$ & $\begin{array}{l}\text { Total } \\
£\end{array}$ \\
\hline Division of non-pension assets & 50,000 & 400,000 & 450,000 \\
\hline Division of pension rights & 795,000 & 445,000 & $1,240,000$ \\
\hline Total & 845,000 & 845,000 & $1,690,000$ \\
\hline \multirow[t]{2}{*}{ Pension share expressed as a percentage } & 795,000 & 445,000 & \\
\hline & $\begin{array}{l}1,240,000 \\
=64 \%\end{array}$ & $\begin{array}{l}1,240,000 \\
=36 \%\end{array}$ & $100 \%$ \\
\hline
\end{tabular}

So divorcing couples ideally should know what assumptions lie behind the CETV and it might well colour the decision about whether or not to choose to share the pension rights.

\section{Conclusions}

In the UK there is well over $\mathcal{E} 1,000 \mathrm{bn}$ in funded pensions alone, averaging at over $£ 50,000$ for each family. In addition there is the entire unfunded public sector, as well as the unfunded entitlements under SERPS (the State Earnings Related Pension Scheme). Including the value of these pensions brings it to about $\mathcal{1} 100,000$ per family.

The emphasis on and funding for pension provision has been steadily growing for decades. The amounts that have been set aside in funded schemes and the value of the pensions promises that have been made in unfunded schemes will inevitably continue to grow as the demographic change of an ageing population develops. All governments will encourage private pension provision, both through occupational schemes and personal and stakeholder pensions.

It is a rather sad fact of life that the complication of detail, some of which is financially important, in pensions provision is likely to increase. Although governments sometimes espouse simplification, the reality is that each new pensions development adds to the complication. Stakeholder pensions are the most recent example. Therefore:

- divorce lawyers will be dealing more and more with valuable but complicated pension rights. They must be aware of the capital nature of pension rights at divorce and be alert to the pitfalls in determining their value

- there will be an onus on pension schemes themselves to provide information to their members in a way which gives the members some chance of understanding the issues presented by divorce. 